LOCKHEED MARTIN

ENVIRONMENTAL RESTORATION PROGRAM
RECENPEO

A46 271096

O S T I

ORNL/ER-369
Sampling and Analysis Plan for White Oak Creek Watershed Remedial Investigation Supplemental Sampling, Oak Ridge National Laboratory, Oak Ridge, Tennessee
This document has been approved by the ORNL Technical Information Office for release to the public. Date: $5 / 30 / 96$

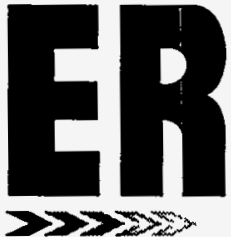




\section{Science Applications International Corporation and CDM Federal Programs Corporation}

contributed to the preparation of this document and should not be considered eligible contractors for its review.

This report has been reproduced directly from the best available copy.

Available to DOE and DOE contractors from the Office of Scientific and Technical Information, P.O. Box 62, Oak Ridge, TN 37831; prices available from 423-576-8401 (fax 423-576-2865).

Available to the public from the National Technical Information Service, U.S. Department of Commerce, 5285 Port Royal Rd., Springfield, VA 22161. 
Energy Systems Environmental Restoration Program

\title{
Sampling and Analysis Plan \\ for White Oak Creek Watershed \\ Remedial Investigation Supplemental \\ Sampling, Oak Ridge National Laboratory, \\ Oak Ridge, Tennessee
}

Date Issued-May 1996

\author{
Prepared for the \\ U.S. Department of Energy \\ Office of Environmental Management \\ under budget and reporting code EW 20 \\ Environmental Management Activities at \\ OAK RIDGE NATIONAL LABORATORY \\ Oak Ridge, Tennessee 37831-6285 \\ managed by \\ LOCKHEED MARTIN ENERGY SYSTEMS, INC. \\ for the \\ U.S. DEPARTMENT OF ENERGY \\ under contract DE-AC05-84OR21400
}




\section{DISCLAIMER}

This report was prepared as an account of work sponsored by an agency of the United States Government. Neither the United States Government nor any agency thereof, nor any of their employees, makes any warranty, express or implied, or assumes any legal liability or responsibility for the accuracy, completeness, or usefulness of any information, apparatus, product, or process disclosed, or represents that its use would not infringe privately owned rights. Reference herein to any specific commercial product, process, or service by trade name, trademark, manufacturer, or otherwise does not necessarily constitute or imply its endorsement, recommendation, or favoring by the United States Government or any agency thereof. The views and opinions of authors expressed herein do not necessarily state or reflect those of the United States Government or any agency thereof. 


\section{DISCLAIMER}

Portions of this document may be illegible in electronic image products. Images are produced from the best available original document. 
APPROVAL PAGE

Sampling and Analysis Plan

White Oak Creek Watershed Remedial Investigation,

Supplemental Sampling at

Oak Ridge National Laboratory,

Oak Ridge, Tennessee

Chis A. Jat hen $5 / 23 / 96$

H. L. Boston, Characterization and Remedial Decision Manager

Aluabeth tain 5-23-96

E. A. Kfispin, Environmental Restoration Project Manager

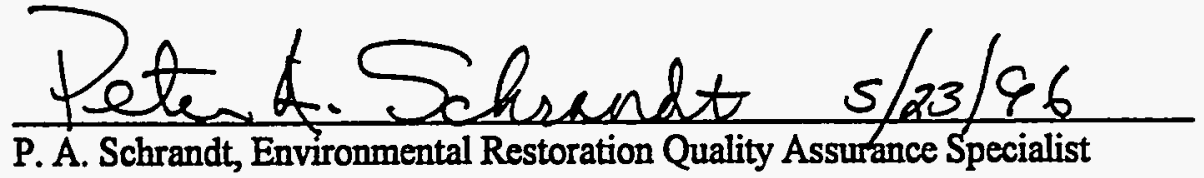




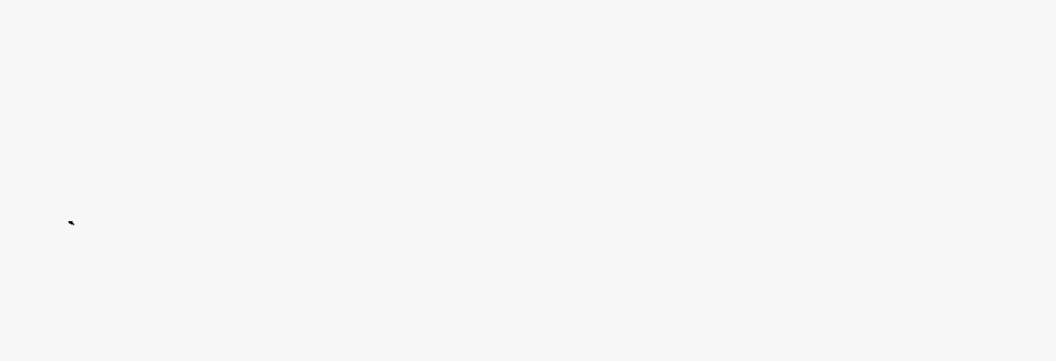




\section{PREFACE}

This Sampling and Analysis Plan for White Oak Creek Watershed Remedial Investigation Supplemental Sampling, Oak Ridge National Laboratory, Oak Ridge, Tennessee, ORNL/ER-369, was prepared to provide support for the White Oak Creek Watershed Remedial Investigation/Feasibility Study. This work was performed under Work Breakdown Structure 1.4.12.6.1.02.45.08 (Activity Data Sheet 3302). This document provides the rationale for surface soil sampling and identifies specific sampling locations, frequencies, and analytes. In addition, it identifies necessary procedures for performing the supplemental sampling. 


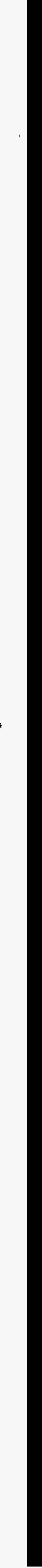




\section{CONTENTS}

TABLE $\ldots \ldots \ldots \ldots \ldots \ldots \ldots \ldots \ldots \ldots \ldots \ldots \ldots \ldots \ldots \ldots \ldots \ldots \ldots \ldots \ldots \ldots \ldots \ldots \ldots \ldots$ vii FIGURES $\ldots \ldots \ldots \ldots \ldots \ldots \ldots \ldots \ldots \ldots \ldots \ldots \ldots \ldots \ldots \ldots \ldots \ldots \ldots \ldots \ldots \ldots \ldots \ldots \ldots$ vii

ACRONYMS $\ldots \ldots \ldots \ldots \ldots \ldots \ldots \ldots \ldots \ldots \ldots \ldots \ldots \ldots \ldots \ldots \ldots \ldots \ldots \ldots \ldots \ldots$ vii

EXECUTIVE SUMMARY $\ldots \ldots \ldots \ldots \ldots \ldots \ldots \ldots \ldots \ldots \ldots \ldots \ldots \ldots \ldots \ldots \ldots \ldots \ldots$ ix

1. INTRODUCTION $\ldots \ldots \ldots \ldots \ldots \ldots \ldots \ldots \ldots \ldots \ldots \ldots \ldots \ldots \ldots \ldots \ldots \ldots$

1.1 OBJECTIVE OF THE WHITE OAK CREEK WATERSHED RI/FS $\ldots \ldots \ldots \ldots$

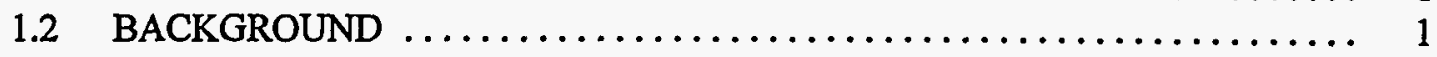

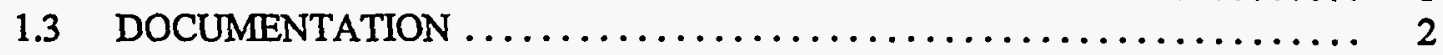

1.4 PROJECT MANAGEMENT STRUCTURE $\ldots \ldots \ldots \ldots \ldots \ldots \ldots \ldots \ldots \ldots$

2. SAMPLING AND ANALYSIS REQUIREMENTS $\ldots \ldots \ldots \ldots \ldots \ldots \ldots \ldots \ldots \ldots$

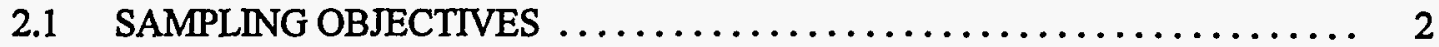

2.2 SAMPLING AND ANALYSIS REQUIREMENTS $\ldots \ldots \ldots \ldots \ldots \ldots \ldots \ldots . \ldots \ldots$

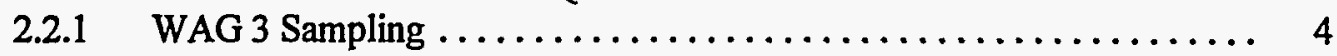

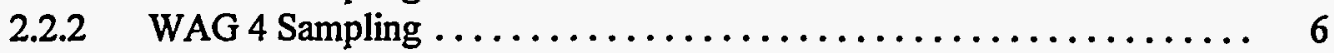

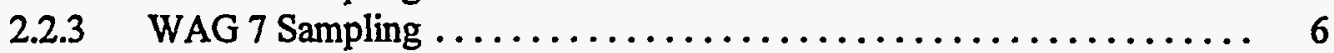

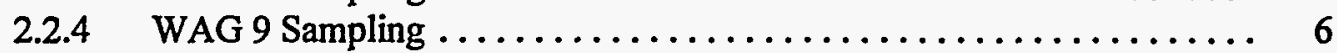

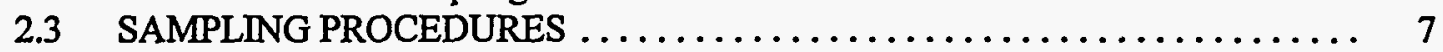

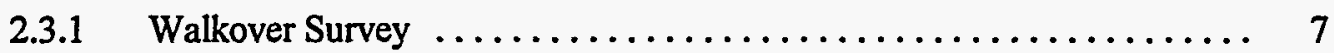

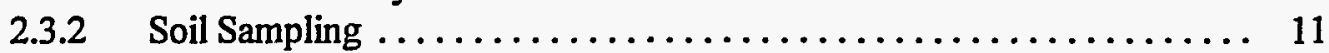

2.3.3 Soil Sample Location Survey $\ldots \ldots \ldots \ldots \ldots \ldots \ldots \ldots \ldots \ldots \ldots, 11$

2.4 ANALYTICAL REQUIREMENTS $\ldots \ldots \ldots \ldots \ldots \ldots \ldots \ldots \ldots \ldots \ldots \ldots \ldots \ldots \ldots$

2.5 DATA MANAGEMENT/DATA VALIDATION $\ldots \ldots \ldots \ldots \ldots \ldots \ldots \ldots \ldots$

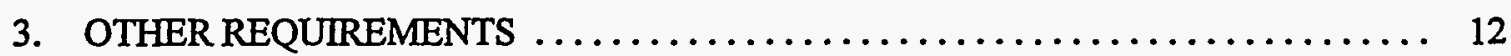

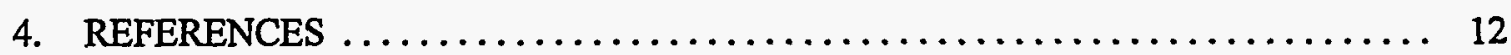

ATTACHMENT A $\quad$ HISTORICAL DATA $\ldots \ldots \ldots \ldots \ldots \ldots \ldots \ldots \ldots \ldots \ldots \ldots \ldots \ldots \ldots$ 


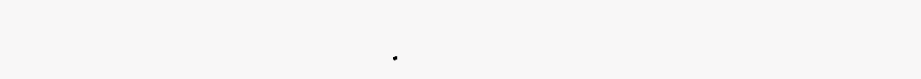

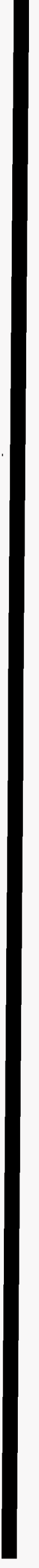


TABLE

1.1 Category 1 waste units at Oak Ridge National Laboratory

\section{FIGURES}

2.1 General location of supplement sampling $\ldots \ldots \ldots \ldots \ldots \ldots \ldots \ldots \ldots \ldots \ldots \ldots$

2.2 WAG 3 radiation walkover survey area $\ldots \ldots \ldots \ldots \ldots \ldots \ldots \ldots \ldots \ldots \ldots \ldots \ldots$

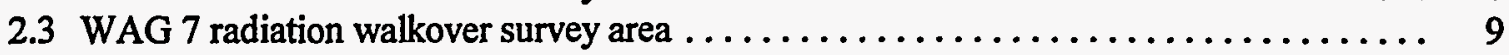

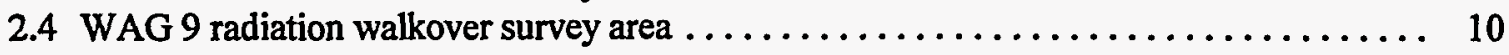

\section{ACRONYMS}

$\begin{array}{ll}\text { CERCLA } & \text { Comprehensive Environmental Response, Compensation and Liability Act } \\ \text { DOE } & \text { U.S. Department of Energy } \\ \text { DQO } & \text { data quality objectives } \\ \text { EPA } & \text { U. S. Environmental Protection Agency } \\ \text { ESP } & \text { environmental sampling procedure } \\ \text { HRE } & \text { Homogenous Reactor Experiment } \\ \text { OHF } & \text { Old Hydro Fracture } \\ \text { ORNL } & \text { Oak Ridge National Laboratory } \\ \text { PCB } & \text { polychlorinated biphenyl } \\ \text { PEMS } & \text { Project Environmental Management System } \\ \text { PPE } & \text { personal protective equipment } \\ \text { QAPP } & \text { Quality Assurance Project Plan } \\ \text { RCRA } & \text { Resource Conservation and Recovery Act } \\ \text { RIFS } & \text { remedial investigation/feasibility study } \\ \text { SAP } & \text { Sampling and Analysis Plan } \\ \text { SOP } & \text { standard operating procedure } \\ \text { SWSA } & \text { solid waste storage area } \\ \text { TDEC } & \text { Tennessee Department of Environment and Conservation } \\ \text { WAG } & \text { Waste Area Grouping }\end{array}$




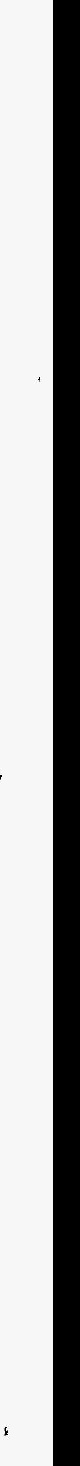




\section{EXECUTIVE SUMMARY}

This Sampling and Analysis Plan (SAP) presents the project requirements for proposed soil sampling to support the White Oak Creek Remedial Investigation/Feasibility Study at Oak Ridge National Laboratory. During the Data Quality Objectives process for the project, it was determined that limited surface soil sampling is needed to supplement the historical environmental characterization database. The primary driver for the additional sampling is the need to identify potential human health and ecological risks at various sites that have not yet proceeded through a remedial investigation. These sites include Waste Area Grouping (WAG) 3, WAG 4, WAG 7, and WAG 9. WAG 4 efforts are limited to nonradiological characterization since recent seep characterization activities at the WAG have defined the radiological problem there.

This SAP is accompanied by the following documentation: Quality Assurance Project Plan, Health and Safety Plan, and Waste Management Plan. 



\section{INTRODUCTION}

This Sampling and Analysis Plan (SAP) has been developed to collect supplemental data for the White Oak Creek Watershed Remedial Investigation/Feasibility Study (RI/FS). The watershed RI/FS is being implemented to define a remediation approach for complying with the Comprehensive Environmental Response, Compensation, and Liability Act (CERCLA) at Oak Ridge National Laboratory (ORNL).

\subsection{OBJECTIVE OF THE WHITE OAK CREEK WATERSHED RI/FS}

The objective of the White Oak Creek Watershed RI/FS is to identify cleanup goals for CERCLA remediation projects. These goals will be developed using the results of a watershed-wide risk assessment and evaluation of remedial process options. The goals will identify contaminant concentrations at specific locations that are protective of human health and the environment and can be achieved in a cost-effective manner.

A secondary objective of the watershed RU/FS is to identify specific actions that can be implemented to achieve the cleanup goals, and a sequence for implementing remediation projects.

A major premise of the watershed approach at ORNL is that, for most areas, available data are sufficient for decision-making. The few areas where the need for additional characterization data has been identified are addressed in this SAP.

\subsection{BACKGROUND}

Early in the process of complying with the CERCLA at ORNL, the plant site and surrounding environs were divided into waste area groupings (WAGs). In general, a WAG was made up of individual waste units that drained through the same subwatershed into the White Oak Creek watershed. A decision was made to perform an individual RI/FS on each WAG.

An RI/FS was completed at WAG 6 first, primarily since a Resource Conservation and Recovery Act (RCRA) investigation was in process. Near the completion of the WAG 6 RI/FS, information collected as part of ongoing surface water and groundwater integrator unit investigations provided a watershed view of contaminant problems at ORNL. This view indicated that WAGs other than WAG 6 , primarily WAGs 1,4 , and 5 , were contributing the majority of off-site contamination. Subsequent investigations of WAGs 1,4 , and 5 pointed to individual waste areas within the WAGs as the major sources of current releases.

It has become apparent over time that the WAG approach does not necessarily lend itself to addressing releases from individual waste units in a logical order, and that a watershed approach is a more coherent, cost-effective approach to addressing the overall contamination problem. Therefore, no other WAG-level RI/FS projects are planned. Instead, a watershed RI/FS is being implemented that identifies cleanup goals for watershed projects and remedial process options for the highest priority waste units in the watershed-regardless of which WAG the units fall within. 
A series of Data Quality Objective (DQO) meetings were held in February 1996 to determine data needs for the White Oak Creek Watershed RI/FS project. The meetings were attended by the Tennessee Department Environmental Conservation (TDEC), the U.S. Environmental Protection Agency (EPA), the U.S. Department of Energy (DOE), and contractors to DOE. This SAP has been developed in response to data needs identified during the DQO meetings.

\subsection{DOCUMENTATION}

Companion documentation to this SAP includes:

- Quality Assurance Project Plan,

- Health and Safety Plan,

- Waste Management Plan, and .

- White Oak Creek Watershed DQO Meeting Minutes, February 15 and 16 and February 26 and 27, 1996.

\subsection{PROJECT MANAGEMENT STRUCTURE}

The project organizational structure for the field sampling effort is identified in the Quality Assurance Project Plan (QAPP).

\section{SAMPLING AND ANALYSIS REQUIREMENTS}

\subsection{SAMPLING OBJECTIVES}

A series of DQO meetings were held in February 1996 to determine data needs for the White Oak Creek Watershed RI/FS project. The meetings were attended by TDEC, EPA, DOE, and contractors to DOE. Data needs were identified and documented in the meeting minutes. Some of the primary assumptions used to identify data needs during the DQO meetings included:

- The watershed RI/FS will focus on the major contaminant sources in the Melton Valley portion of the White Oak Creek watershed. "Major" is defined by criteria such as "total curie inventory," "magnitude of existing releases to receiving streams," and "percentage contaminant contribution to off-site releases at White Oak Dam." The major sources are identified in Table 2.1 and are defined as "Category 1" units. The remaining sources in the watershed will be addressed to a lesser extent in the RI/FS process. Additional data needs have been identified for the Category 1 units only.

- No additional data are necessary to perform a watershed FS that identifies, at a minimum, process options for the Category 1 units; however, at most sites, additional data will be required to design and implement a remediation. For a small subset of sites (1 to 3 sites), available information is sufficient to implement a remedial action within 15 months of an approved decision. 
Table 2.1. Category 1 waste units at Oak Ridge National Laboratory

\begin{tabular}{cl}
\hline WAG & \multicolumn{1}{c}{ Sites } \\
\hline WAG 2 & White Oak Creek tributaries and floodplain \\
& White Oak Lake \\
& White Oak Creek Embayment \\
WAG 4 & WAG 4 Seeps Areas 1,2,3,4,5, and 6 \\
& WAG 4 tritium trench \\
WAG 5 & SWSA 5 South A \\
& SWSA 5 South B \\
& SWSA 5 South C \\
& SWSA 5 South D \\
& Undefined Trenches \\
& WOC Dump Area \\
WAG 6 & 7852A OHF Pond \\
& Northeast Auger Hole \\
& High Activity Trenches \\
WAG 7 & 19 Trench Area \\
& 49 Trench Area \\
WAG 9 & Pits 2,3,4 \\
WAG 10 & Trench 5,7 \\
& HRE Pond \\
HRE $=$ & New Hydrofracture Wellhead \\
OHF $=$ & Old Hydrofracture Wellhead \\
SWSA $=$ & Old Hydro Fracture \\
WOC $=$ & Solid waste storage area \\
& White Oak Creek
\end{tabular}

- During the DQO meeting, it was believed that the estimates of human health risk associated with exposure to radionuclides would be sufficient for baselining the need for action, but that impacts associated with additional analytes, mainly metals, would be needed to baseline ecological risks. Since the DQO meeting, it has been determined that the human health risk assessment would also use nonradiological data to assess total risks at a site.

- Sites for which RIs have already occurred (WAG 5, WAG 6) do not need additional characterization. Characterization efforts should be directed towards Category 1 sites that have not been through an RI.

- In areas for further investigation, it is assumed that nonradiological contaminants are co-located with radiological contaminants. 


\subsection{SAMPLING AND ANALYSIS REQUIREMENTS}

This section provides a summary of supplemental sampling requirements for the watershed RI/FS. The primary rationale for the planned sampling is the fact that potential ecological risks can not be characterized using only radiological data, the type of data most often collected in many historical characterization efforts. Whereas radionuclides dominate the human health risk, they do not drive ecological risks. For this reason, as identified during DQO meetings, the need to characterize ecological risks becomes the greatest impetus for additional sampling.

Although most identified sampling is source-specific surface soil sampling, it was determined that a single surface water sample was needed to fill an existing data gap. The WAG 2 Phase 1 RI produced a comprehensive set of wet season and dry season baseflow grab analytical results, including radionuclides and metals. At one location along Melton Branch, just downgradient of the HFIR impoundments, no wet season metals data were generated. It was determined that filling this gap would help support the understanding that the WAG 8 impoundments contribute relatively little to risk in the watershed. A sample was collected at this site in March during a sampling event that took place as part of the ongoing ORNL surface water program sampling. The sample was analyzed for metals.

Figure 2.1 shows the general location of surface soil sampling activities. Provided below is a summary of the surface soil sampling.

\subsubsection{WAG 3 Sampling}

Scope: Characterize nature of surface soils in three WAG 3 waste units: the Solid Waste Storage Area (SWSA) 3, the Metal Scrap Yard, and the Contractors Landfill.

Sample Location/

Frequency: Use historic radiological walkover survey results and hand-held radiological meters to locate three previously identified soil hot spots in western half of Contractors Landfill. Collect one surface soil sample ( 0 to $1 \mathrm{ft}$ ) in each of the three hot spot locations.

Use historic walkover survey results and hand-held meters to locate four soil hot spots in SWSA 3 area; collect one surface soil sample ( 0 to $1 \mathrm{ft}$ ) at each of four hot spot locations and one sample at each of three random (non-hot spot) locations within SWSA 3.

Collect three surface soil samples ( 0 to $1 \mathrm{ft}$ ) in the Metal Scrap Yard area, based on visual indications of buried waste.

Sample

Type: $\quad$ Surface soil ( 0 to 1 feet)

Analytes: $\quad$ Landfill and SWSA 3: gross radiation ( $\alpha, \beta$, and $\gamma)$, isotopic uranium, metals, and polychlorinated biphenyls (PCBs); Metals Scrap Yard: metals and PCBs. 


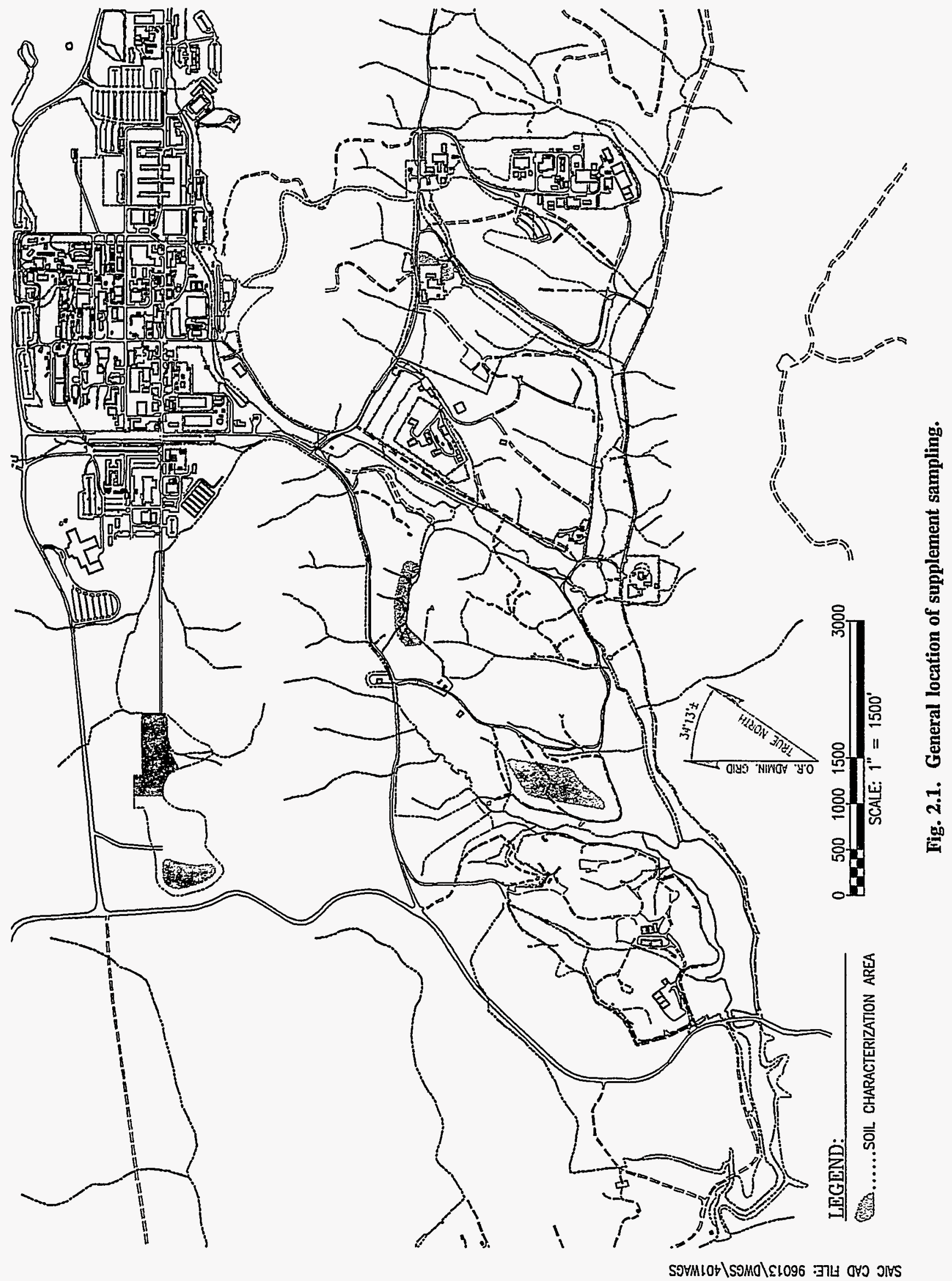




\subsubsection{WAG 4 Sampling}

Scope: $\quad$ Characterize nonradiological constituents in surface soils in WAG 4 seeps area to characterize nonradiological risks to human health and terrestrial ecological receptors.

Sample Location/

Frequency:

Locate areas of soil contamination using the WAG 4 field crew guide, existing flags, stressed vegetation, and radiological survey meters. Collect seven surface samples ( 0 to $1 \mathrm{ft}$ ): four from hot spot locations, three from random (non-hot spot) locations in the vicinity of the seep area.

Sample

Type:

Surface soil $(0$ to $1 \mathrm{ft})$

Analytes: $\quad$ Metals (all samples), PCBs (four hot spot samples only).

\subsubsection{WAG 7 Sampling}

Scope: $\quad$ Characterize surface soil downgradient of Pits 2, 3, and 4, focusing primarily on areas of documented or suspected historical seepage.

Sample Location/

Frequency:

Perform a $\gamma / \beta$ radiation walkover survey in the areas downgradient of Pits 2,3 , and $4(\sim 4$ acres). Using the results of the radiation survey and visual inspection, locate and characterize the surface soil at seven historical seep areas and collect surface soil samples ( 0 to $1 \mathrm{ft}$ ) at four random (non-hot spot) locations downgradient of Pits 2,3 , and 4 . In addition, collect one sample at Line Leak Site $7 \mathrm{~b}$.

Sample

Type:

Surface soil $(0$ to $1 \mathrm{ft})$

Analytes: $\quad$ Gross radiation $(\alpha, \beta$, and $\gamma)$ : isotopic uranium, ${ }^{99} \mathrm{Tc},{ }^{239} \mathrm{Pu},{ }^{230} \mathrm{Th},{ }^{237} \mathrm{~Np}$; metals; and PCBs.

Special

Consideration: Sampling may require Level C personal protective equipment (PPE).

\subsubsection{WAG 9 Sampling}

Scope: $\quad$ Collect surface soil samples to help characterize nonradiological risks to ecological receptors from Homogenous Reactor Experiment (HRE) Impoundment and contamination detected in drainage to the east of HRE Impoundment. Conduct interviews with personnel knowledgeable about HRE processes and the Melton Valley Facility Manager to help understand the source of contamination in the drainage.

Sample Location/ Frequency:

Perform a visual site survey and radiological walkover survey around the HRE impoundment and to the east of the HRE. Collect three surface soil ( 0 to $1 \mathrm{ft})$ samples at hot spots in the floodplain soils in the drainage area east of HRE. 
Collect four surface soil samples in contaminated areas around and downgradient of the HRE pond.

Sample

Type:

Surface soil ( 0 to $1 \mathrm{ft}$ ); floodplain soils ( 0 to $1 \mathrm{ft}$ )

Analytes: $\quad$ Gross radiation $(\alpha, \beta$, and $\gamma)$, isotopic uranium, metals, and PCBs.

Special

Consideration: Sampling may require Level C PPE.

\subsection{SAMPLING PROCEDURES}

Soil sampling will be conducted in accordance with existing Environmental Restoration environmental sampling procedures and ORNL standard operating procedure (SOP)-environmental sampling procedures (ESP), including:

- $\quad$ ESP-102

- ESP-303-1 Rev. 1

- ESP-404

- ESP-405-1/ESP 900

- ESP-501

- ESP-502

- ESP-503

- ESP-504

- ESP 1000

- SOP-ESP-003.11
Field Quality Control

Collection of Soil Samples

Sample Preservation, Containers, and Holding Times

Decon Requirement for Sampling Equipment

Chain of Custody

Sample Identification

Field Log Books

Field Monitoring Equipment Calibration

Management of Decon Fluids

Sampling of Soil and Sediment; 7.1 Surface Soil Sampling with Spade, Trowel, Knife, Spoon, or Spatula

- SOP-ESP-003.012 Sampling Document Control.

\subsubsection{Walkover Survey}

As outlined in the sampling strategy, a radiological survey will precede identification of surface soil sampling locations at WAGs 3,7, and 9. The areas for walkover are identified by dark lines on Figs. 2.2, 2.3, and 2.4. These areas have been identified based on results of historical surveys or historical radiological soil sampling (Energy Systems 1996, and Attachment A). The figures show some boundaries indicated with a dashed line. The actual extent of the walkover in these areas may be increased depending on the readings at the dashed boundaries. If readings are two times $(2 \times)$ background, the extent of the survey will increase to the point where readings are below $2 \times$ background.

Radiation walkover surveys will be conducted using a sodium iodide probe. The procedure for identifying hot spots is provided below:

- Radiation areas $>2 \times$ background will be flagged.

- If an area of $>10 \mathrm{ft}^{2}$ is identified as $2 \times$ background, the flag will be placed at a central location in the contaminated area. The approximate circumference of the area will be noted in the field logbook. 


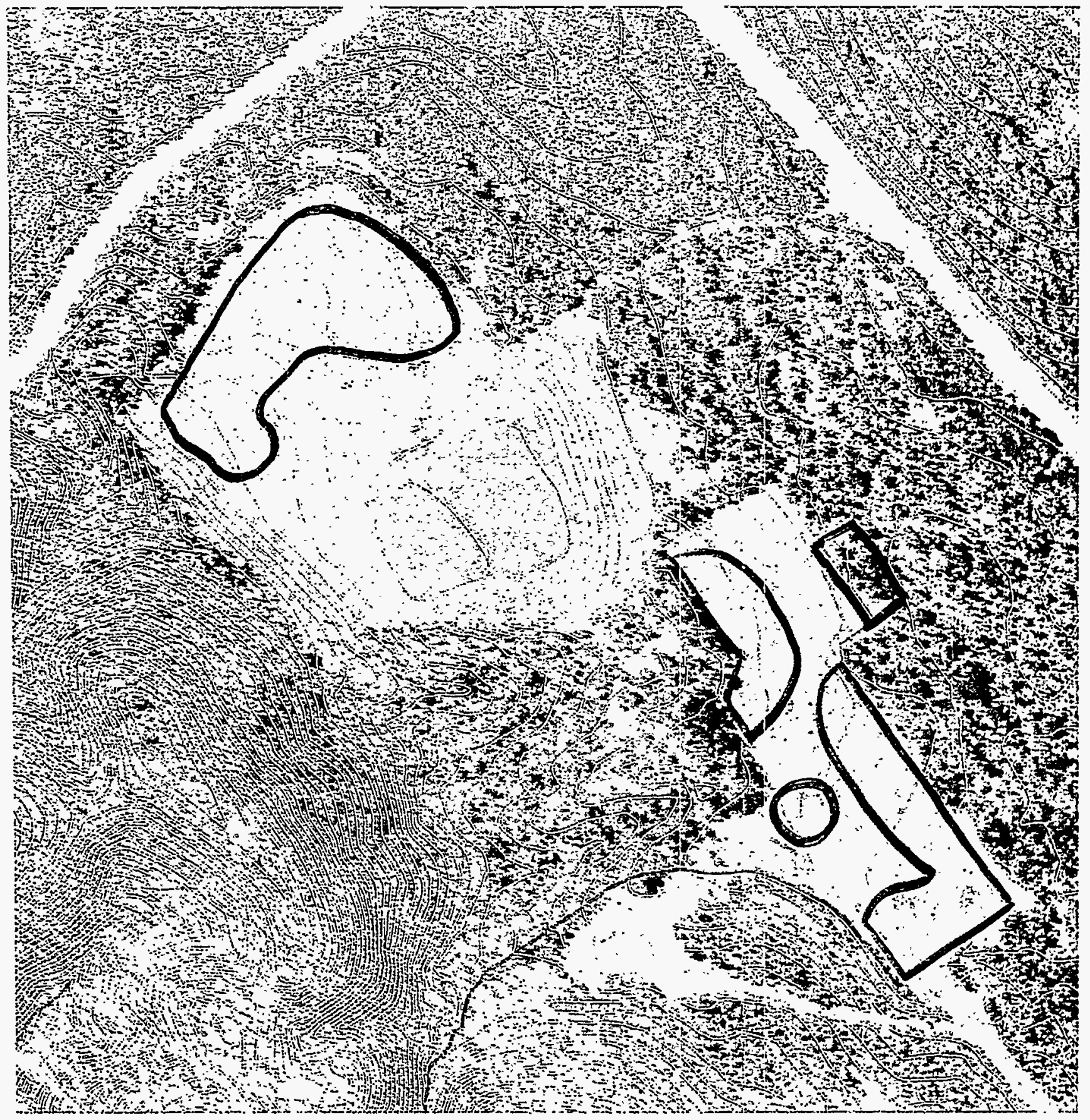

Fig. 2.2. WAG 3 radiation walkover survey area. 
9

$4 \times 1, * 4$

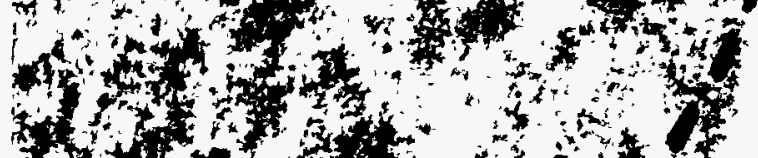
$17 x+3,1$ 040 .

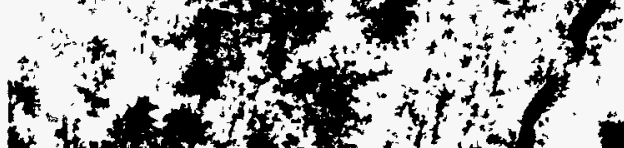
How , 3,1 Ning 诰, , s.t. Why

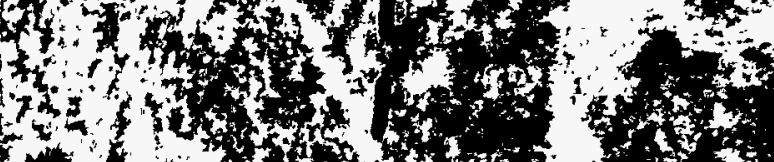
(4)

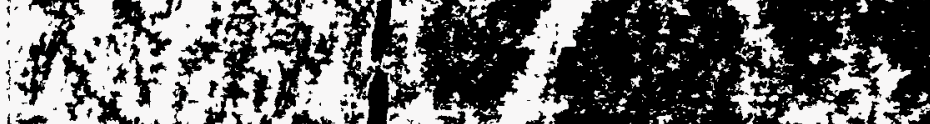
If (n)

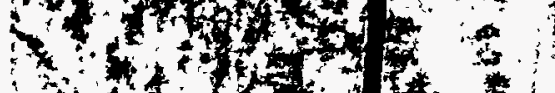

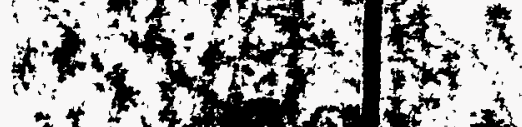
(3)

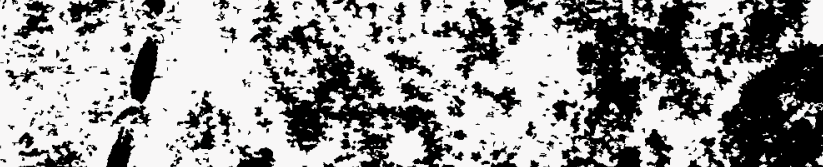
13 $x_{x \rightarrow+\infty}$

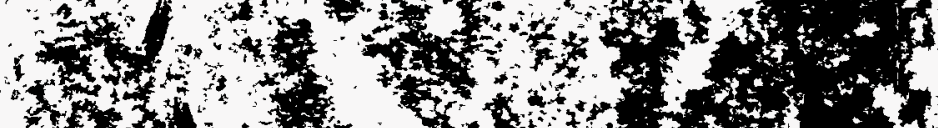

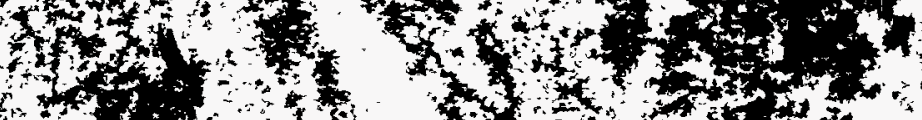

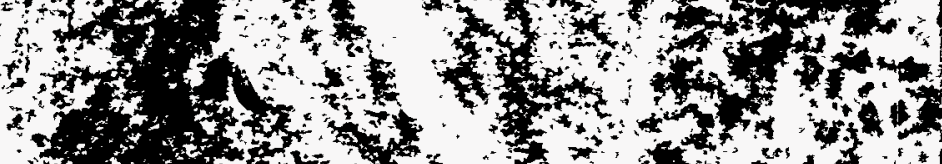
(3)

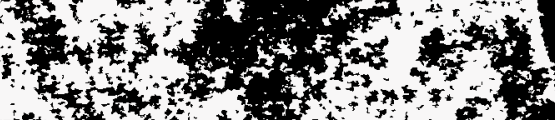

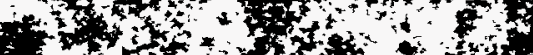

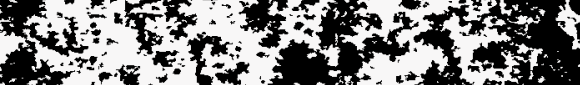

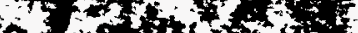

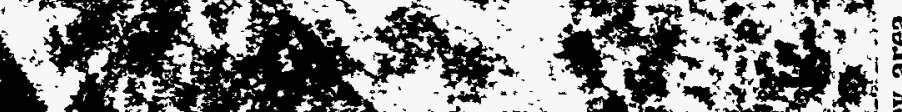
(3)

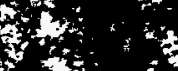

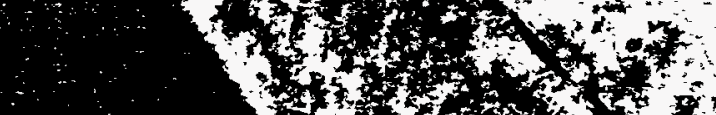

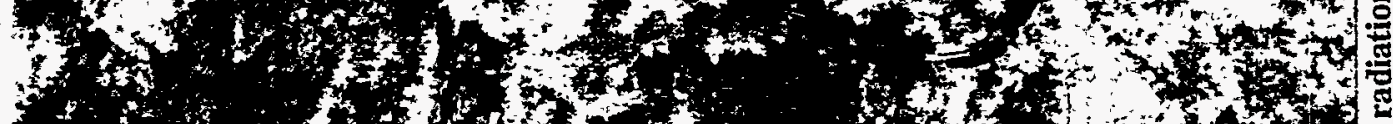
a (3)

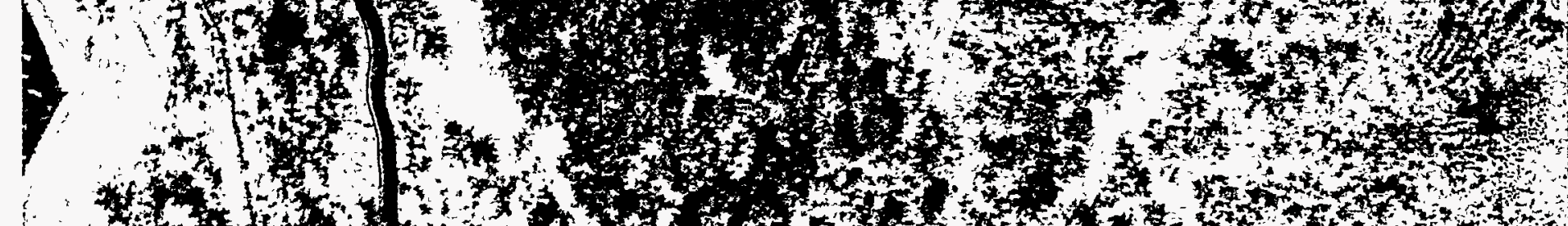

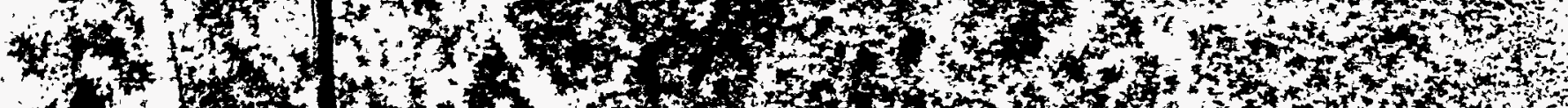

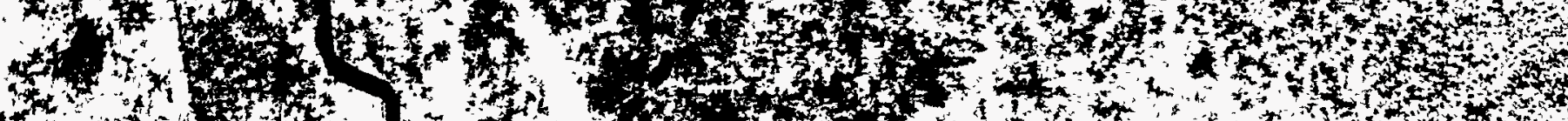

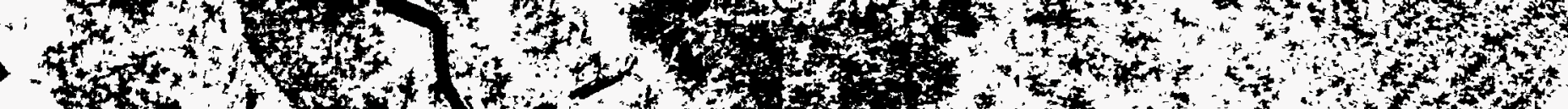

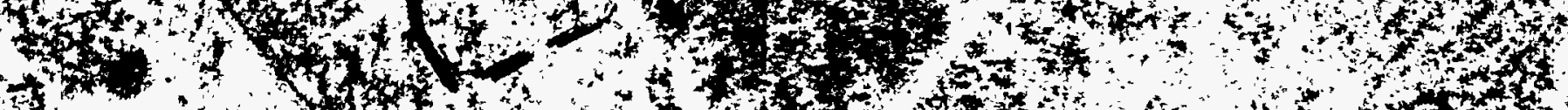
1 15

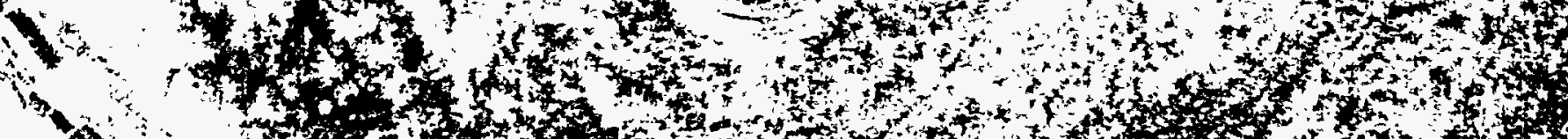

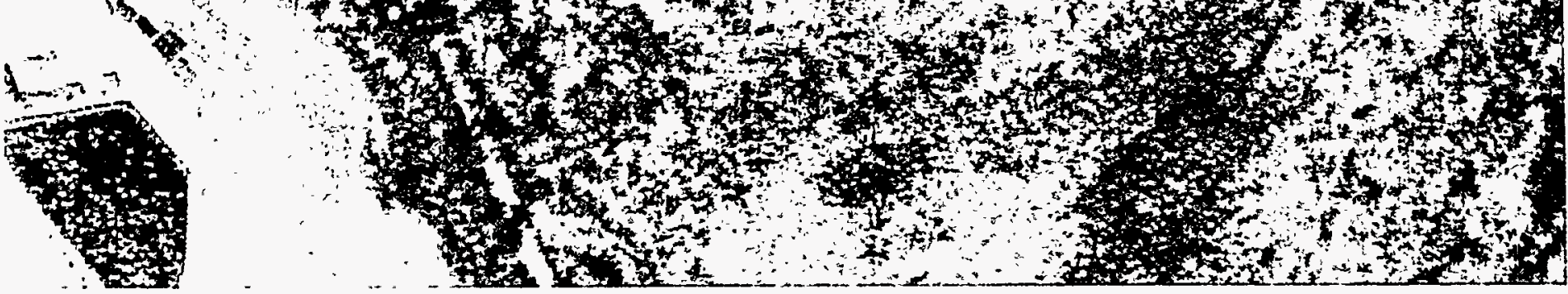




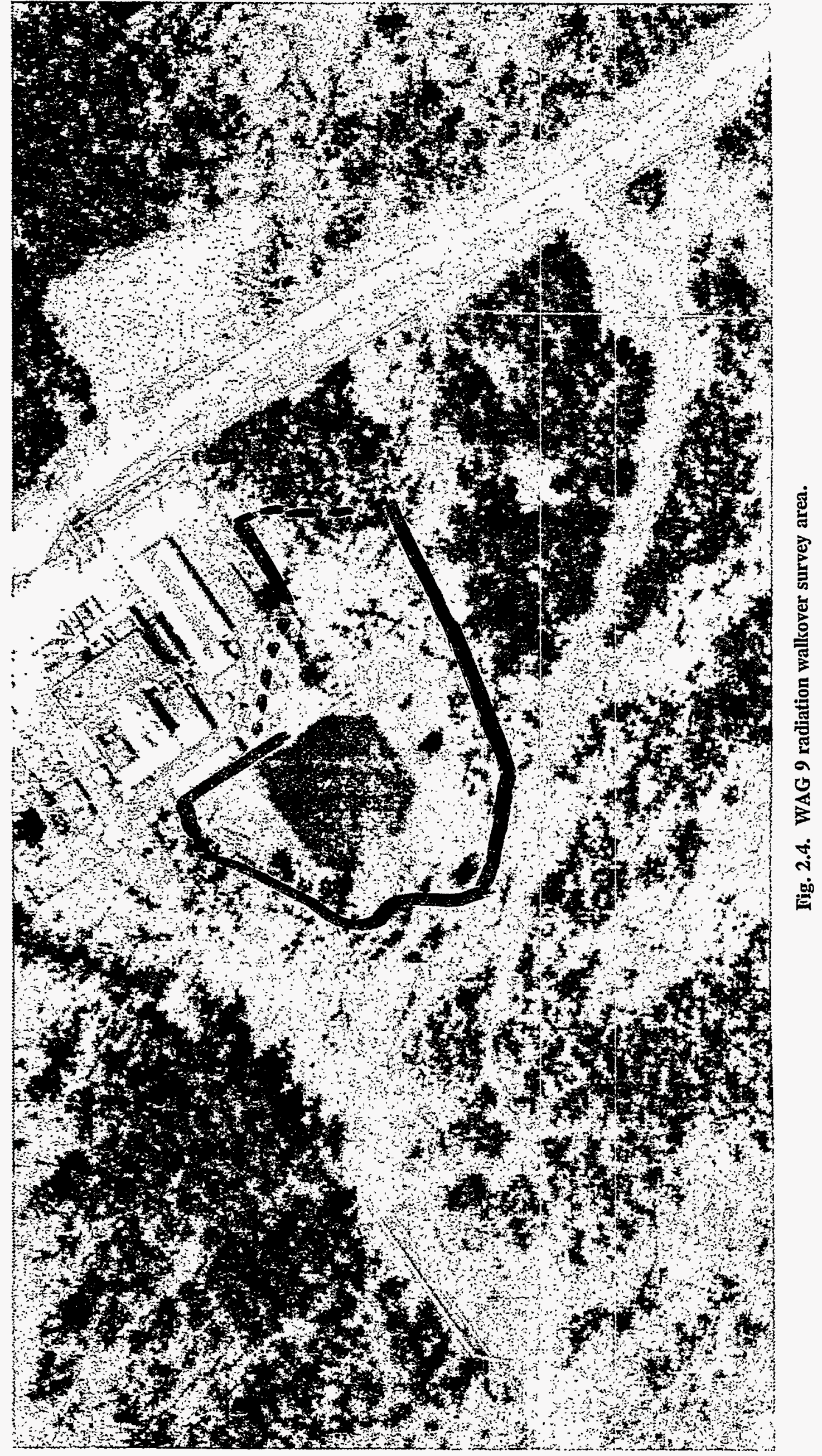


- Each flag will be numbered, and a reading will be recorded in the field logbook for each flag.

- Approximate locations of areas $>2 \times$ background and flag locations will be identified to the extent possible on a site map, but will not be surveyed.

Technical team members will review the entire range of hot spot readings and identify the exact soil sampling locations for each WAG prior to sampling. Random samples will be taken in areas where readings are $<2 \times$ background.

Soil sampling locations for WAG 4 will be identified by project personnel involved in recent seep characterization activities. Many "hot spots" can be identified by existing flags and stressed vegetation. These areas will be confirmed as hot spots using a hand-held meter.

\subsubsection{Soil Sampling}

Field operations for soil sampling will follow SOP-ESP-003.11, "Sampling of Soil and Sediment; 7.1 Surface Soil Sampling with Spade, Trowel, Knife, Spoon, or Spatula" (Energy Systems 1994a). Sample handling and sample identification requirements, i.e., chain-of-custody requirements, will follow procedures laid out in Requirements for Quality Control of Analytical Data for the Environmental Restoration Program, ER/ES/TM-16 (Energy Systems 1992) and the Project Environmental Management System (PEMS) requirements (Energy Systems 1994b).

Quality control sample requirements include:

- one field blank (of deionized water) will be collected at the onset of the field work,

- $\quad$ one rinsate sample will be collected for every 10 soil samples collected $(10 \%)$,

- one duplicate sample will be collected for every 10 soil samples collected (10\%), and

- $\quad$ one matrix spike/matrix duplicate will be collected for every 20 soil samples collected ( $5 \%$ ).

\subsubsection{Soil Sample Location Survey}

Soil sample locations will be surveyed using Global Positioning Survey instruments; coordinates will be converted to the ORNL plant coordinate system.

\subsection{ANALYTICAL REQUIREMENTS}

Analytical work will be performed in accordance with ER/ES/TM-16 (Energy Systems 1992). As identified during the DQO workshop, analysis will be limited to radiological analyses, metals, and PCBs. Analytical method requirements are listed in Tables 7.1 and 7.2 of the QAPP for radiological and nonradiological analytes, respectively. Practical quantification limit requirements for all analytes are listed in Table 7.3 of the QAPP.

Laboratory quality control requirements and sample types are discussed in detail in the QAPP.

\subsection{DATA MANAGEMENT/DATA VALDATION}

Data management and data validation activities will be performed in accordance with ER/ES/TM-16 (Energy Systems 1992) and Data Management Plan and Functional System Design for the Information Management System of the Clinch River Remedial Investigation and Waste Area 
Grouping 6 (Energy Systems 1994b). All data from the contract laboratory will be received in electronic format and placed in the PEMS database. Contract Laboratory Program data packages will be generated by the analytical laboratory and sent to the project files and data validators.

Data validation will be performed to ensure that the precision and accuracy of the analytical data are adequate for their intended use. Because the greatest uncertainty in a measurement is often a result of the sampling process and inherent variability in the environmental media rather than the analytical measurement, validation will be performed only to the level necessary to minimize the potential of using false positive or false negative concentrations in the decision-making process (i.e., assure accurate identification of detected versus nondetected compounds).

A minimum of $10 \%$ of project data will be evaluated by data validation criteria consistent with the guidelines in TM-16 Level D validation. The $10 \%$ subset of the project data will be selected with respect to sample medium, analytical method, analytical laboratory, and project schedule (i.e., sample data packages will be selected throughout the project). The remaining $90 \%$ of the project data will be validated based on a reduced set of TM-16 Level C validation criteria.

\section{OTHER REQUIREMENTS}

Health and safety requirements and waste management requirements are addressed in the Health and Safety Plan and the Waste Management Plan. The Health and Safety Plan supplements Health and Safety Plan for Environmental Restoration Program at Oak Ridge National Laboratory (Energy Systems 1994c). The plan identifies project-specific requirements that were not addressed in the previous plan. The Waste Management Plan was developed specifically for the supplemental RI sampling.

\section{REFERENCES}

Energy Systems (Martin Marietta Energy Systems, Inc.). 1992. Requirements for Quality Control of Analytical Data for the Environmental Restoration Program, ER/ES/TM-16, Oak Ridge, Tennessee.

Energy Systems. 1994a. "Sampling of Soil and Sediment; 7.1 Surface Soil Sampling with Spade, Trowel, Knife, Spoon, or Spatula, " SOP-ESP-003.11, Oak Ridge, Tennessee.

Energy Systems. 1994b. Data Management Plan and Functional System Design for the Information Management System of the Clinch River Remedial Investigation and Waste Area Grouping 6, Oak Ridge, Tennessee.

Energy Systems. 1994c. Health and Safety Plan for Environmental Restoration Program at Oak Ridge National Laboratory, ORNL/ER-226, Oak Ridge National Laboratory, Oak Ridge, Tennessee.

Energy Systems (Lockheed Martin Energy Systems, Inc.). 1996. Data Summary Package for the White Oak Creek Watershed Remedial Investigation/Feasibility Study Data Quality Objectives Workshop, Oak Ridge, Tennessee. 
ATTACHMENT A

HISTORICAL DATA 


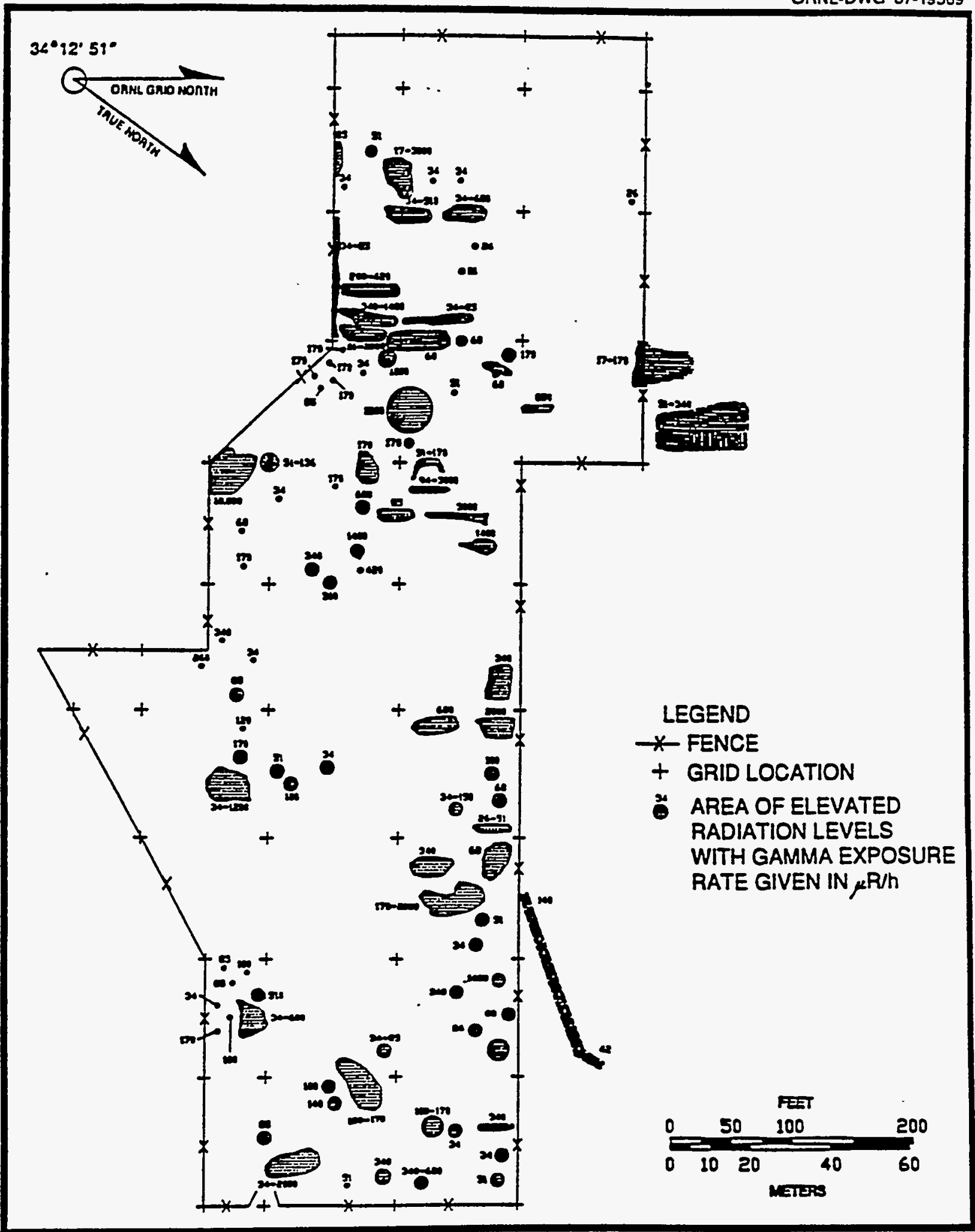

SOURCE: Uriel el al. (1988).

FIGURE 3-18

LOCATION OF SURFACE CONTAMINATION

AT SWSA 3 (AUGUST 1987) 


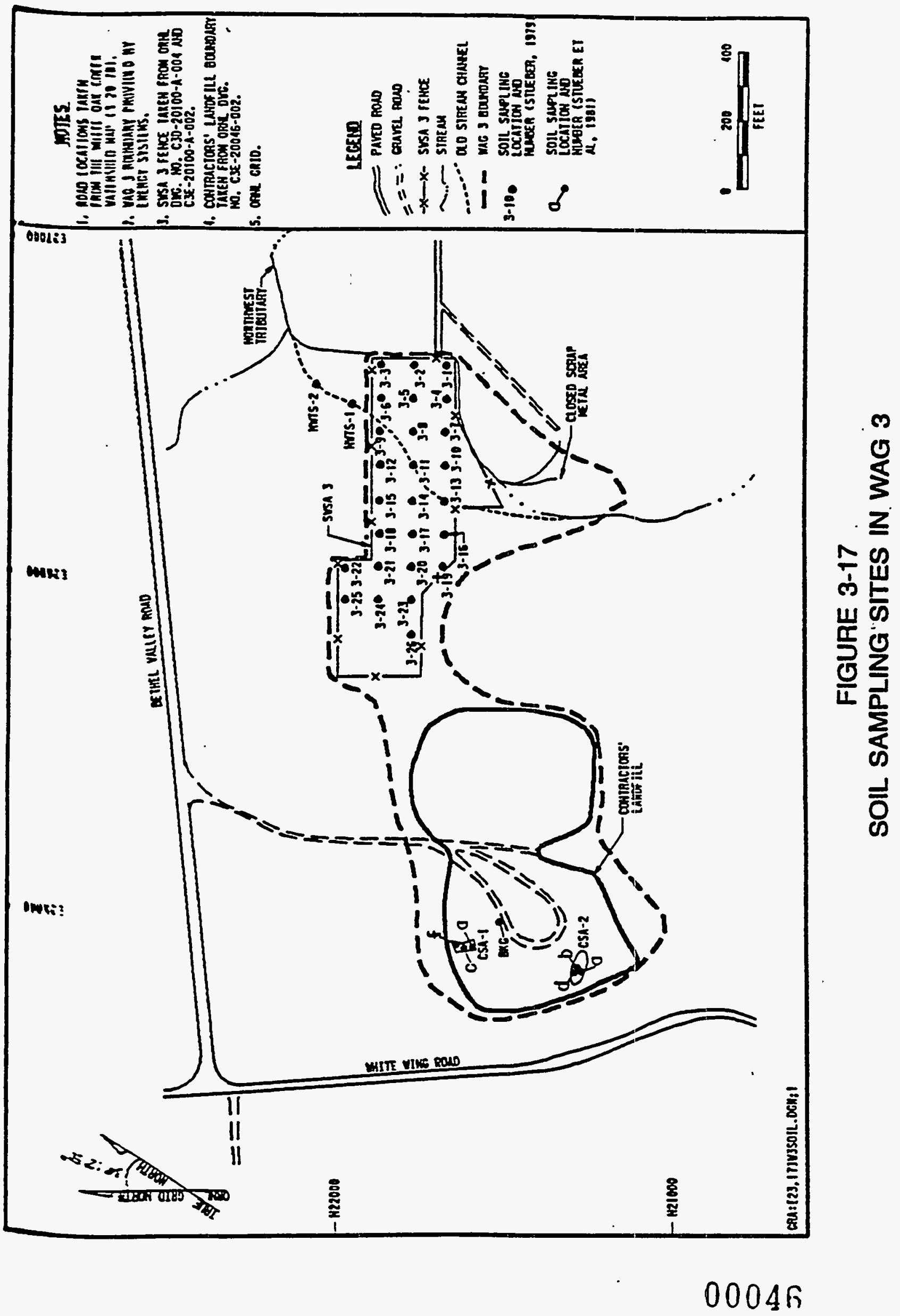




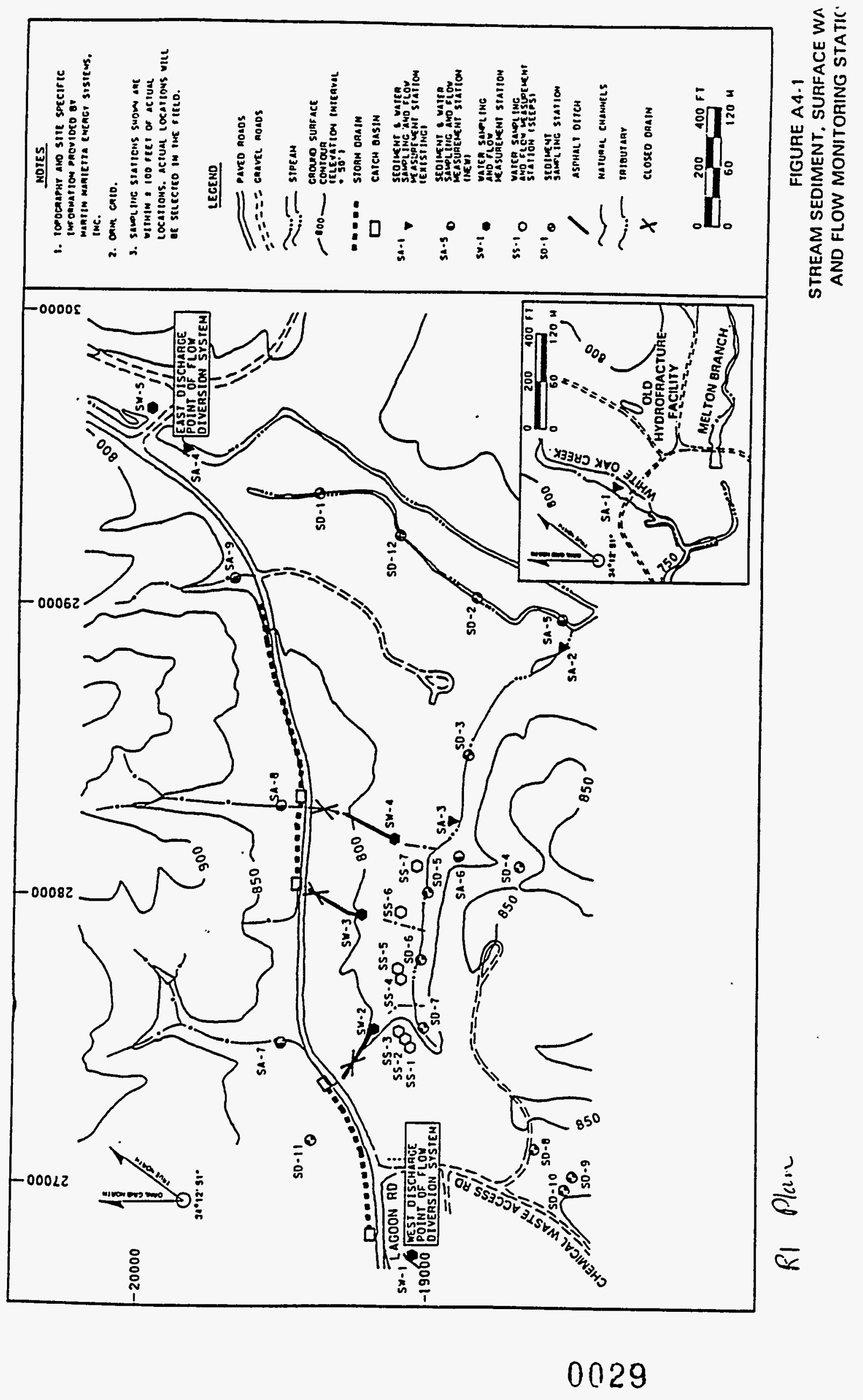




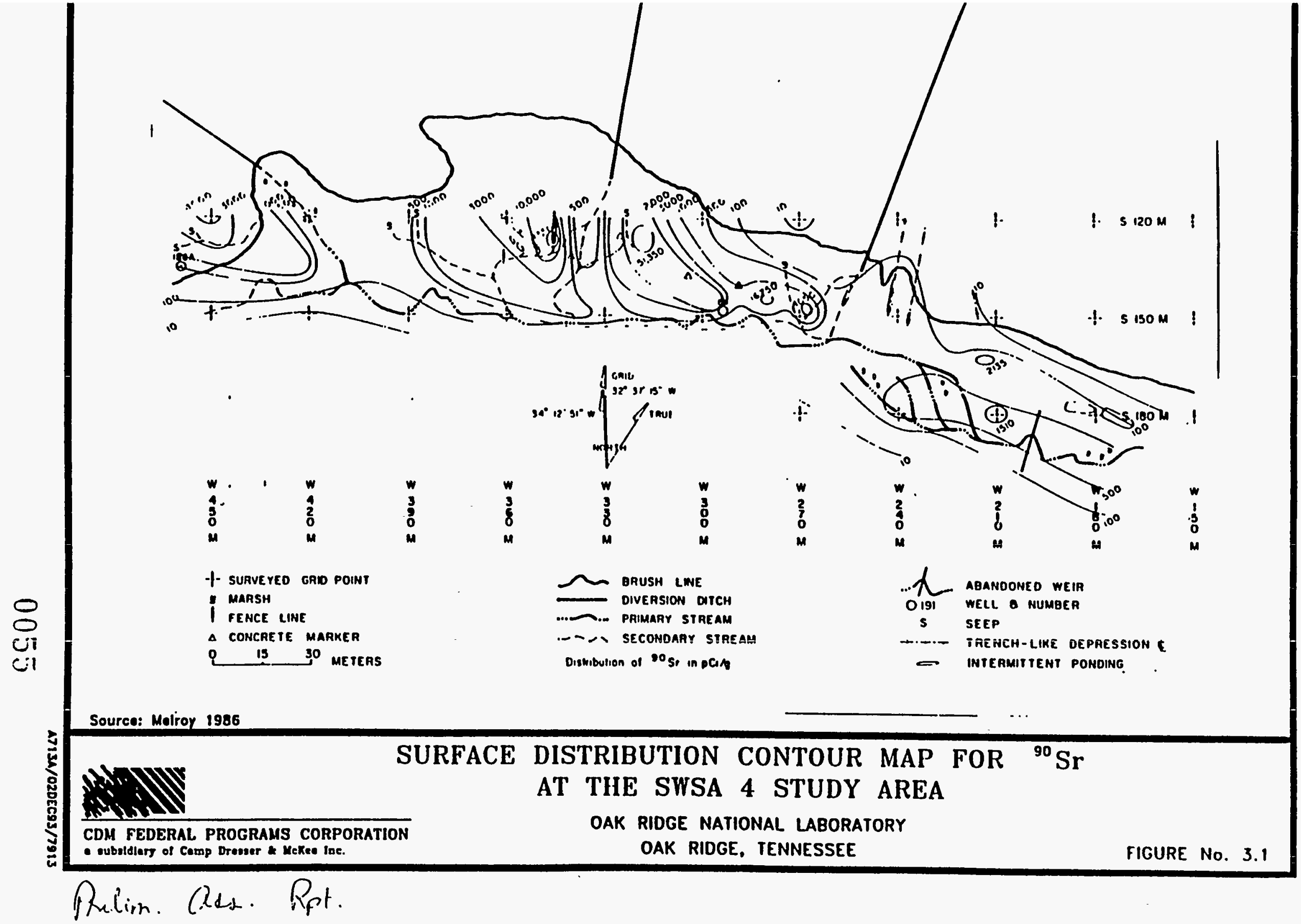




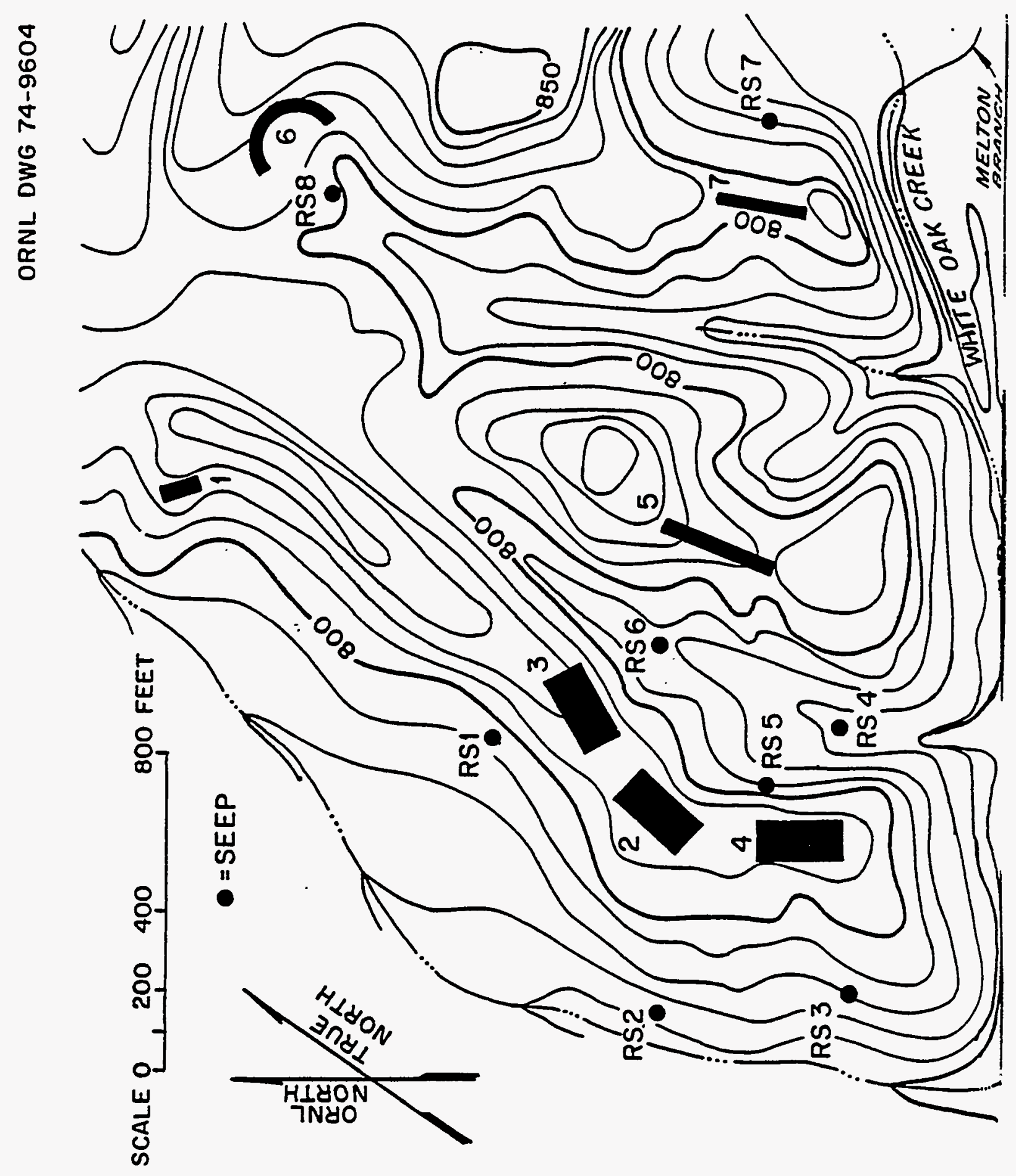

Witi 7

ORNL-DWG-74-9604 1974

Seep locations around pits and trenches

Williams and Uzjel. MADD 


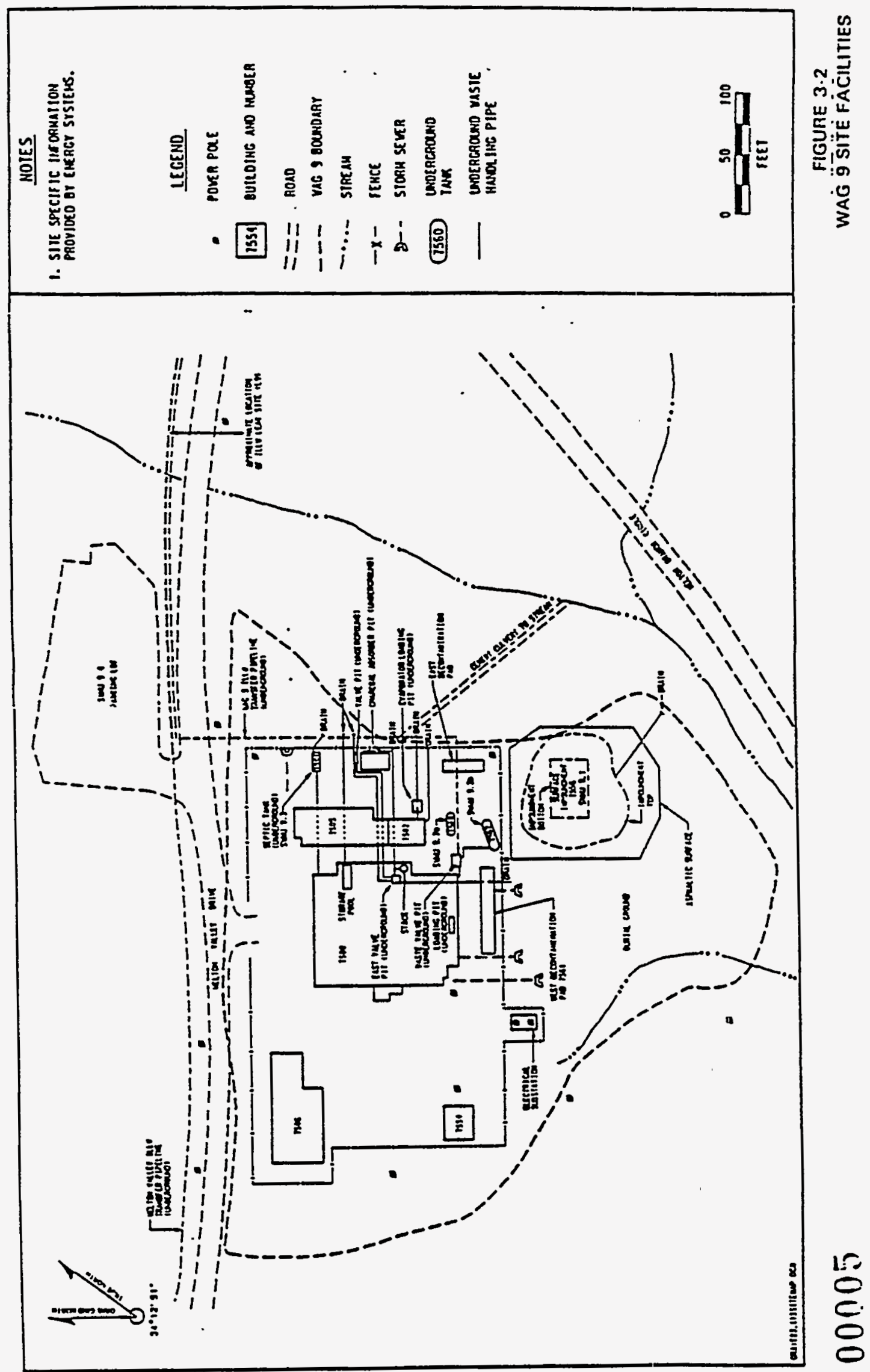




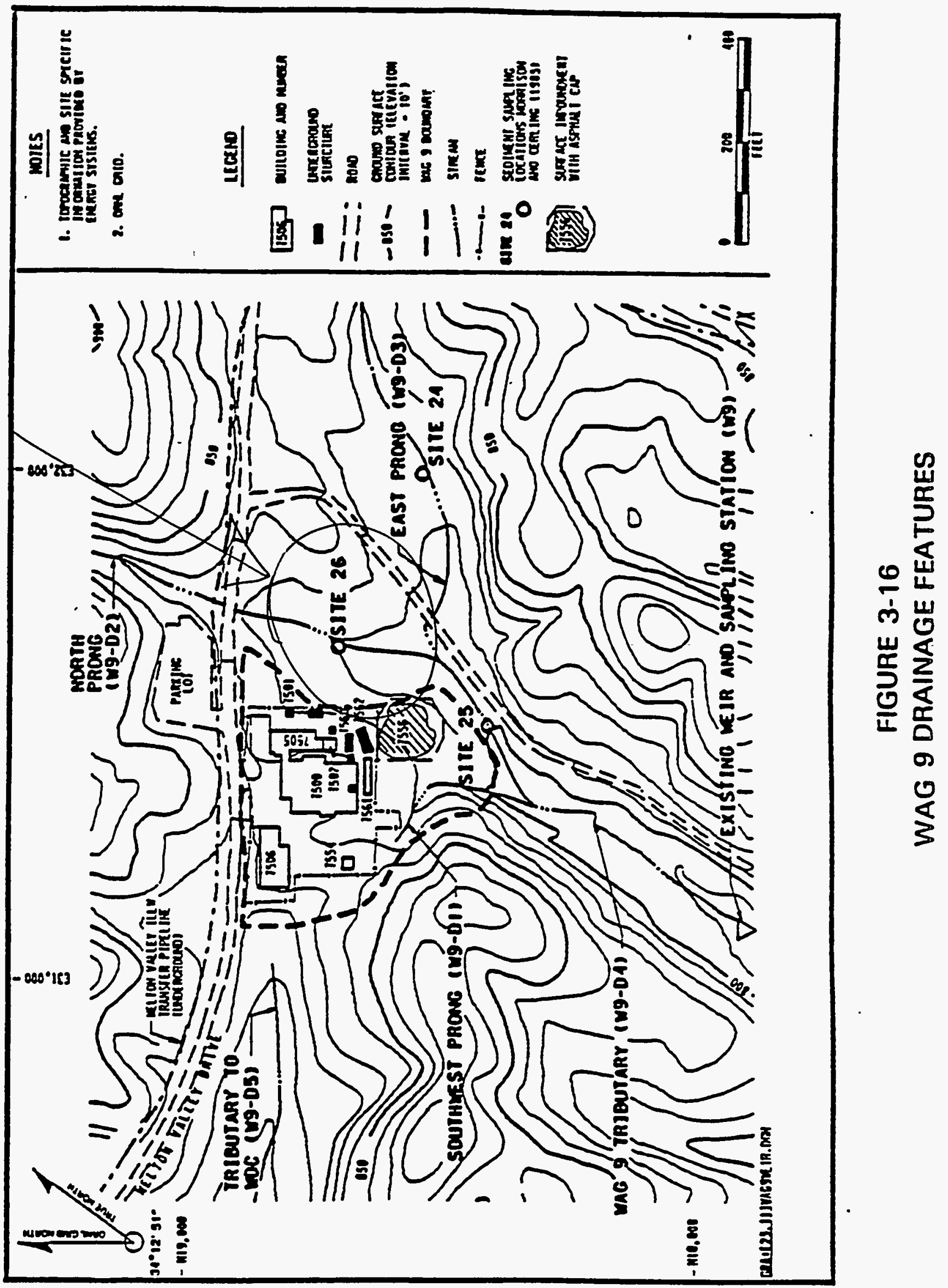




\section{DISTRIBUTION}

1. L. V. Asplund

2. H. L. Boston

3. W. D. Brickeen

4. C. Clark, Jr.

5. R. Foley

6. J. E. Francis

7. D. L. Garrett

8. L. S. Hawk

9. P. Hofmann

10. R. H. Ketelle

11. E. Krispin

12. D. M. Matteo

13. P. L. Osborne

14-15. P. T. Owen (2)

16. C. Rightmire

17. A. W. Saulsbury

18. P. A. Schrandt

19. C. S. Swinney

20. K. Wilson

21. Central Research Library

22. ER Central Doc. Mgmt. Center-RC

23. Office of Scientific and Technical Information, P.O. Box 62, Oak Ridge, TN 37831

24. M. Goldberg, CDM Federal Programs Corporation, 800 Oak Ridge Turnpike, Oak Ridge, TN 37830

25. S. Pack, Science Applications International Corporation, P.O. Box 2502, Oak Ridge, TN 37831 